\title{
BOYS' AND GIRLS' SECTION
}

Edited by Joyce Dew, Saskatchewan Museum of Natural History



Any young person may submit material for this section of the Blue Jay. The entries must be first-hand observations in the form of letters, stories, poems, black - and - white sketches or photographs. Letters should not exceed 500 words. All entries must be accompanied by the name, age, and address of the sender.

Book prizes or magazine subscriptions will be awarded with each issue of the Blue Jay. Special prizes will be given from time to time to teachers who encourage their pupils to write or who sponsor nature activities about which the children write.

Send in your nature observations to Boys' and Girls' Section, Blue Jay, Miss Joyce Dew, Saskatchewan Museum of Natural History, Regina. The closing date for the next issue is October 15, 1960.

PRIZE WINNER for this issue is Margaret Houston, age 6, who wins the prize for her delightful poems about a Robin. We look forward to hearing more from her.

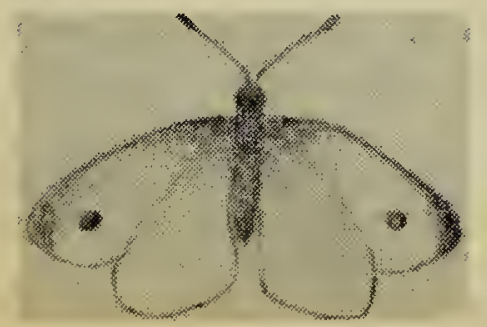

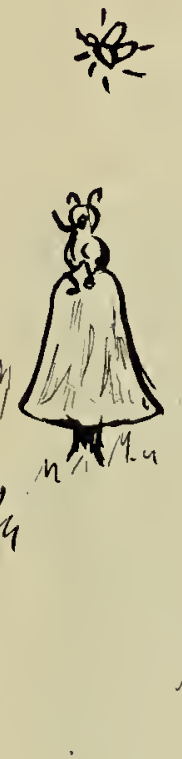

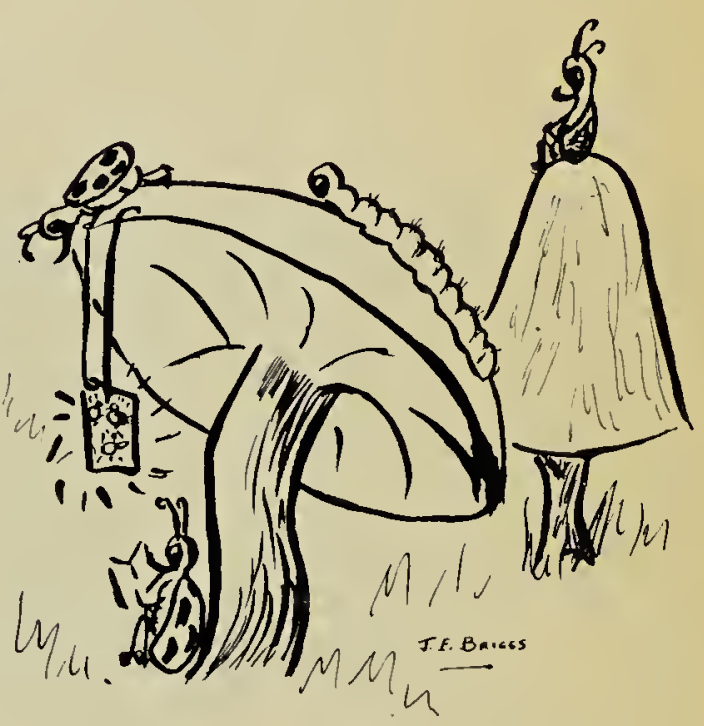

\section{NEWS FROM JUNIOR MEMBERS}

Most of the Junior Members appear to be busy observing birds. Peter Tsakires of Regina reports having seen a Canada Goose on Wascana Lake in Regina and was quite thrilled with it. This would be one of the geese from the Regina Waterfowl Park. They spend much of their time in the Waterfowl Park but sometimes delight picnickers on the Legislative Grounds by putting in an appearance in that area.

Lorne Graupe spent some time looking at a water bird and sent us a description as well as a drawing of it. We agree with you Lorne, it certainly sounds as if you saw a Ruddy Duck. Lorne is interested in hawks as well and sent in several drawings of them.

Surprising things sometimes happen when you knock down an old log in the bush as Duane Hillaby of Codesa, Alberta, discovered. Duane heard a buzzing noise in the log and found four young woodpeckers inside.

Ed Shepherd continues to keep us informed about his bird banding. activities and his nest recording. He is fortunate in having someone like Dr. Stuart Houston to give him 
assistance and advice about such activities. Now that the Houstons have moved to Saskatoon they will be missed in the Yorkton area.

We have tried to make the "name the bird" contest harder this time, but hope we haven't made it too hard for you. If you want a checklist of the birds of Saskatchewan write to the Saskatchewan Museum of Natural History, Regina.

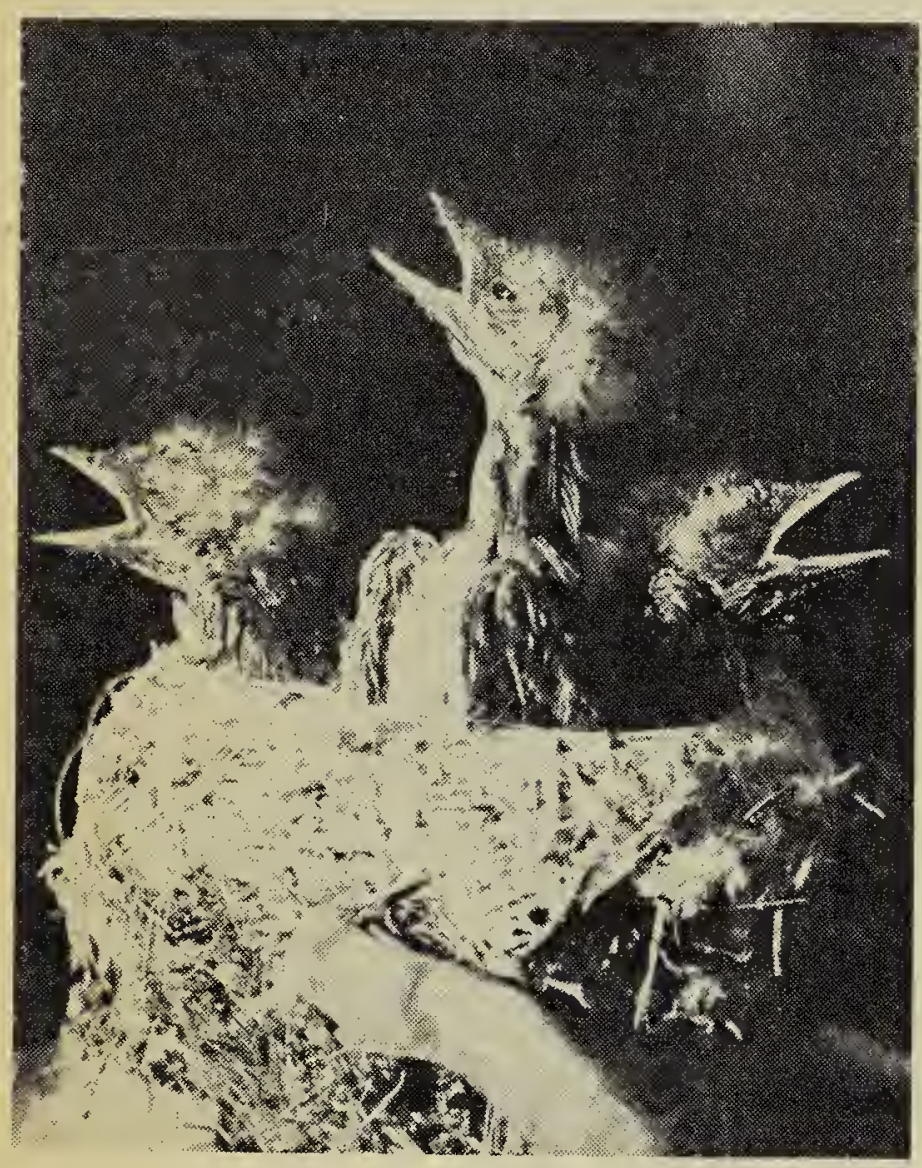

Photo by Kay Hodges A hungry young family

\section{HIKING}

by the pupils of Shamrock School

Date: June 7 th.

Time: 2.00 to 3.00 o'clock.

Distance: Around the school yard and about one quarter mile down a lane, across a hill, back to the road, and back to the school again. On our hike we saw the following things:

Plants-Wild mint (which we pressed), vetches (two or three kinds), cowslip, blue violets, lily of the valley, meadow rue, star grass, white anemone buds, wild parsnip leaves, white cup shaped flowers, tiny blossoms in the grass with four petals the size of a pin head, toadstool.

Trees and Shrubs-Aspen, caraganas, poison ivy, pincherry in blossom (the pincherry leaves are finer than chokecherry leaves, lighter green in color, and very finely toothed), saskatoon (leaves rounded, edge roughly toothed, many of the blossoms are gone and the small berries are formed), chokecherries in blossom (leaves are darker and rougher than pincherries, many blossoms were falling), wild raspberries, wild honeysuckle (bud), willows in bloom, seeds are formed, wild roses in bloom along the roadside.

Mammals-Two brown rabbits in the bluffs beside the schoolyard.

Insects-We found a rotted log and when we turned it over there were large red ants under it. We saw several low worn down ant hills with little black ants. We never saw the eggs, larvae, or pupa in any of the nests. On the way home we found a large insect which was lying flat on the ground in the grass. Teacher thought it was a butterfly. It couldn't fly so we took it back to school and when we observed it more closely it had feathery feelers, a large hairy body and six strong legs. It was a Ceceropia Moth. We are keeping it to start a collection. We also saw Black Beetles, spiders and many webs, blue butterfly, a white butterfly, a black butterfly with white bordered wings probably a iMourning Cloak, a Tiger Swallowtail butterfly (yellow and black).

Birds-There are barn swallows in the school yard. They rest on the power line, and fly in and out of the chimney. In the yard is song Sparrow's nest in the grass, with four tiny blue eggs in it. The bird flew out when we were about a yard from it. We saw a female blackbird on a power pole. We heard bird songs but couldn't identify the song, or see the bird.

We hope to go on another longer hike next week and we will find the plants in bud to see what the blossoms are like. 


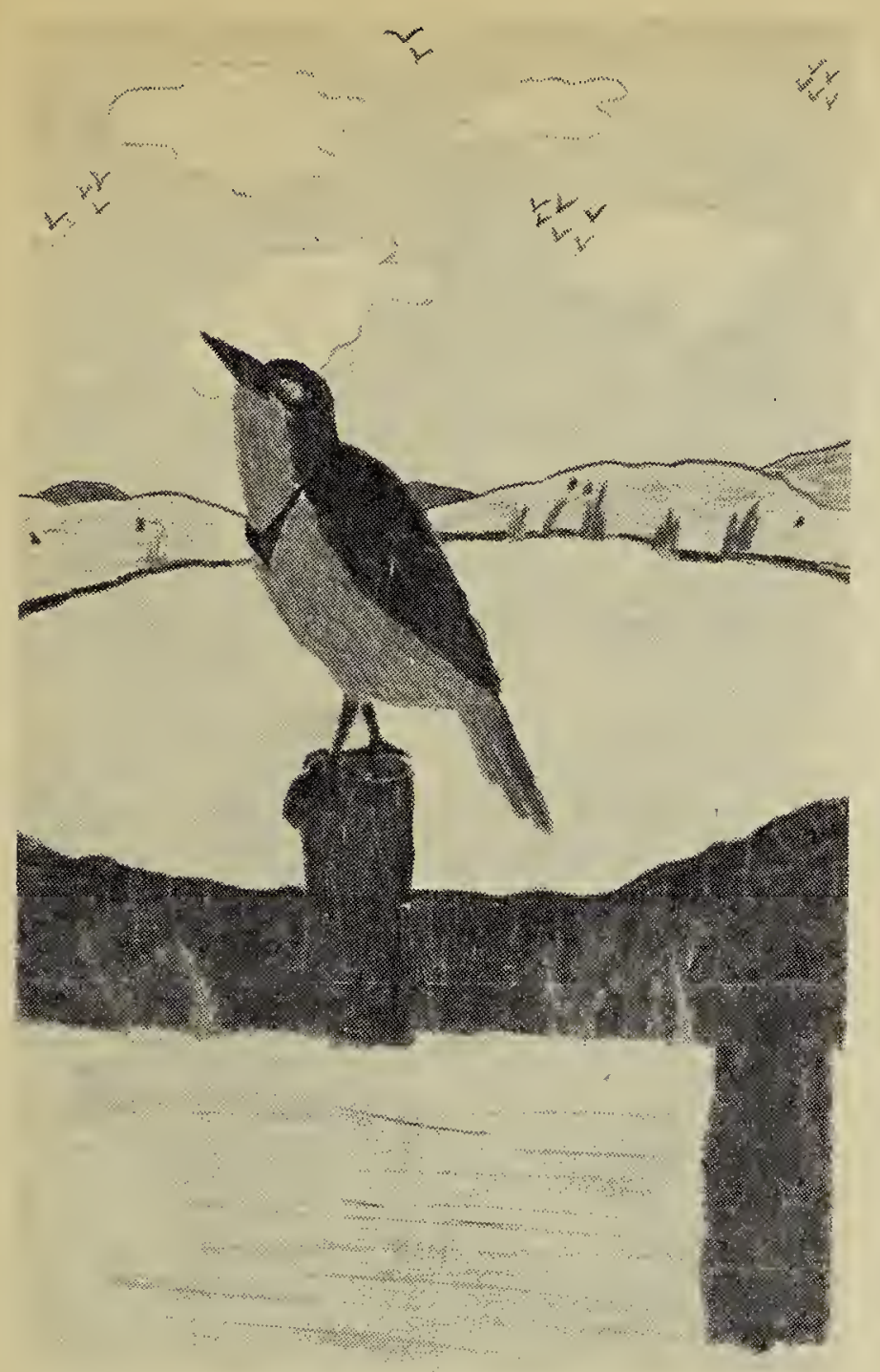

MEADOWLARK

by Shiela Carlson, Estevan, Sask.

\section{BIRD BANDING AND NEST OBSERVATIONS}

by Ed Shepherd, Invermay, Sask.

On Monday, May 23rd, Victoria Day, I spent the day with Dr. Stuart Houston, banding Great Horned Owls (young ones). Out of eight nests, we banded twenty young ones and are about to band some Long-eared Owls and Marsh Hawks. Myself, I found four Marsh Hawk nests which isn't very many and also four Long-eared Owl's nests. I also found two Mourning Dove's nests and when Dr. Houston sent me the bands to band them they were already gone, but that is just my luck.

There are many Coot nests because I found eight around one little corner of Saline Lake. One nest had twelve eggs in it. Also I found one Pied Billed Grebe's nest and two Eared Grebe's nests. Both Eared Grebes had six eggs and the Pied Billed Grebe only had two.

Note.-Ed also tells us about the contest he has entered finding Owl nests for Dr Stuart Houston and lists some of the nests he has found. He reports as well that he has seen a Jumping Mouse and that a Whooping Crane was seen going over their school on May 3rd. "It was not too high but was quite large and white. His body was not of a stocky type but slim and it had a long stretched out neck."

\section{TWO UNEXPECTED VISITORS \\ by Gordon Sawchuk, age 13, Endeavour, Sask.}

Early one morning when I came to school I saw a pair of beautiful Barn Swallows sitting on the map case. I tried to chase them out but did not succeed in doing so. When our teacher, Mr. Hutchinson, arrived at school, he, my friend Jack and I tried to get them to fly out but they were just too smant for us. When the bell rang one girl was scared of those harmless little birds, but somehow we got her convinced that they wouldn't bite or hurt her.

All that morning the Barn Swallows sat on the map at the front of the room, acting just like a pair of keen teachers. After dinner Mr. Hutchinson darkened the room, left the door open and thought that the birds would fly to the light outside but they didn't. At last, at recess we managed to get rid of one but one still remained. My grade had to stay in after school to take a class. All of a sudden from outside we heard a Barn Swallow chirping away and as quick as a wink the Barn Swallow that was inside the school flew out. I guess it was its mate calling it.

\section{THE ROBIN}

by Margaret Houston, age 6, Yorkton, Sask.

\section{The Robin's Nest}

I saw a nest up in a tree

That soine robins built

Where I could see.

\section{A Robin Sings}

I heard a robin in a tree Sing

A song to me. 


\section{OBSERVING OWLS}

by Lorne Graupe, Hazen, Sask.

It was April 30th I found the nest and on May 1st I decided to climb the tree. As I started to climb the tree the owls flew off hooting loudly. When I was about halfway up the tree, the owls.began snapping their beaks very loudly, and sort of meowing like a cat. For two weeks I passed the owl's nest quite frequently. About June 5th the owls were quite big and my friend and ! decided to take one home and show Mom and Dad. As we neared the nest at the top of the tree, the owls started the same procedure as before, also making dives at us. We finally got the owl down to the ground and my friend stood over it, looking at it. We knew they were Great Horned Owls and that they were dangerous. As he stood over it, the female owl dived at him. I saw it and yelled at him. He ducked just in time and the owl missed him by about eight inches. We took the owl home and got a picture of it. Then we took it back. I didn't go back until about a week later and then they were gone.

\section{CEDAR WAXWINGS}

by Sally Moss, age 11, Regina, Sask.

A couple of Sundays ago Dad and I went to Rotary Park in Regina and to a slough we know about five miles outside Regina. When we went to Rotary Park I saw ten Cedar Waxwings, beautifully colored. I have never seen them before so it was a great thrill. Most of the birds seemed to be scared of us, so we didn't see too many birds except at the slough. The chief birds we saw at the slough consisted of grebes, geese and two Avocets.

\section{A JANUARY BUTTERFLY}

by Ralph Underwood, Age 13, Strasbourg, Sask.

One January evening my brother found a cabbage butterfly in the house. We caught it and put it in our Christmas tree. The next day we couldn't find it. The next night we found it, almost dead, on the floor. After picking him up we mixed a small amount of sugar with a little water in a teaspoon. We offered it to him. Out shot his tongue and he began sucking the liquid up. When he had had enough he neatly curled his tongue up and flew off. We fed him for ten days; then he died.

\section{CLUES FOR "NAME THE BIRD" CONTEST}

1. The adults of these young are pictured elsewhere in this contest.

2. The name of this owl begins with " $\mathrm{S}$ ". It is a buffy brown color and has an irregular flopping flight.

3. When adult this duckling will have prominent yellow-colored eyes.

4. This bird frequently "gangs up" with others of its species to attack larger birds such as crows.

5. This bird was featured in the June issue of the Blue Jay.

6. This bird has a chicken-like yellow bill and inhabits marshes.

7. This is one of the three following birds: Sea Gull, Bonaparte's Gull, Common Tern.

8. This gull is one of the following: Ring-billed Gull, Sea Gull, California Gull.

9. These birds nest in Saskatchewan.

10. Visitors to the A.O.U. in Regina last summer saw several thousands of these birds.

11. These geese nest north of Saskatchewan.

12. These large white birds migrate through Saskatchewan and nest further north.

13. This fairly large white bird is sometimes mistaken for a Whooping Crane.

14. This bird is one of the following: Bonaparte's Gull, Sea Gull, Common Tern.

\section{RESULTS OF "FACT FINDING" CONTEST}

We would like to thank the boys and girls for their enthusiasm and the good response we had to this contest. Question Number 7 was unintentionally confusing so we did not count it in the marking. In some issues of the "Blue Jay" the reproduction of the photograph of the Sage Grouse chicks was so poor that it was impossible to count the number of young. In judging the contest, we looked first for the entries with all answers correct and eliminated those with incorrect answers. Next we looked for completeness of answer 
and accuracy of spelling, particularly the correct copying of the names of mammals and birds.

The winners were as follows:

Children 12 and under: Louisa Mountain, age 9, Lloydminster, Sask.

Children 13-16: A tie between Jimmy Lynowski, age 14, Veregin, Sask., and Maxine Wilson, age 16, Broadview, Sask.

Everyone who entered the contest is being sent a Saskatchewan Natural History Society calendar since we still have a few of this year's calendars on hand. We can't promise that we can do this for every contest though.

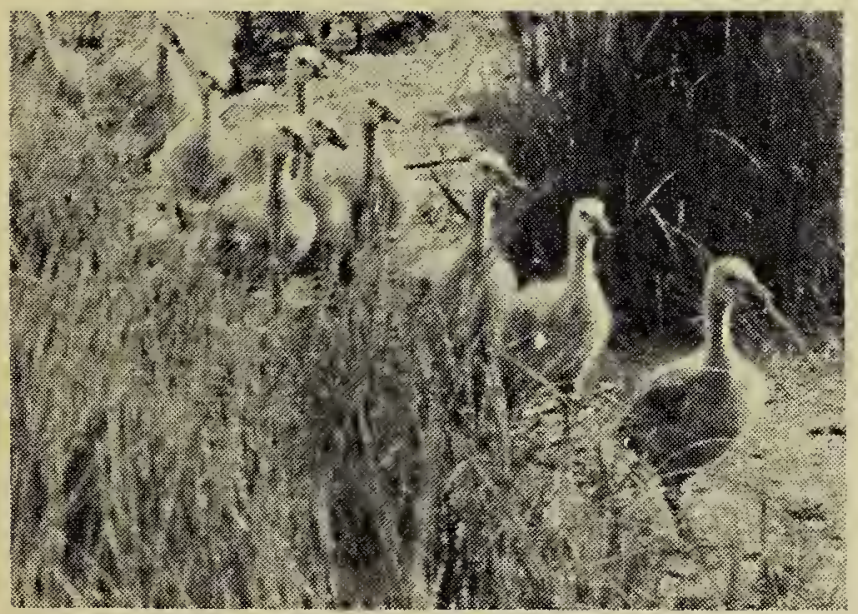

1

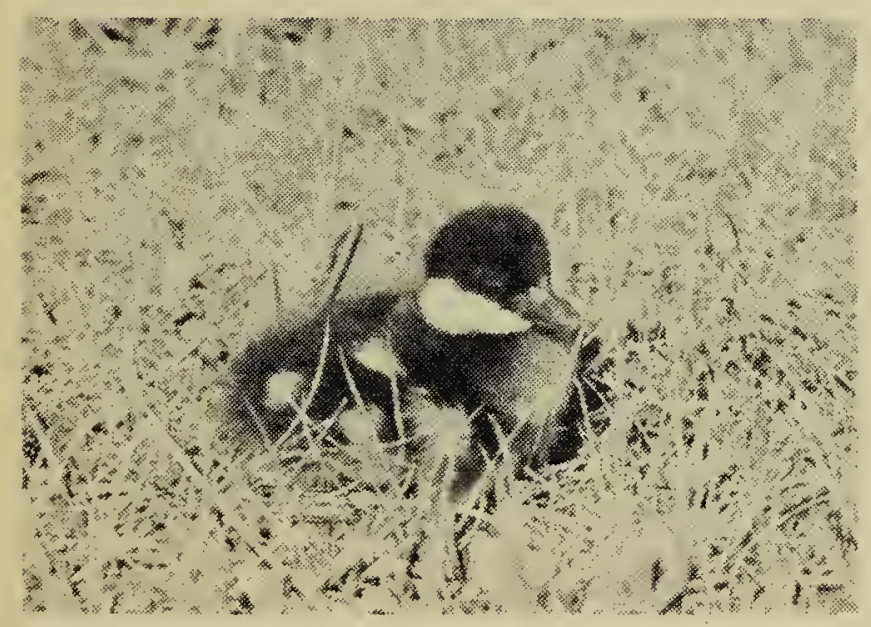

3

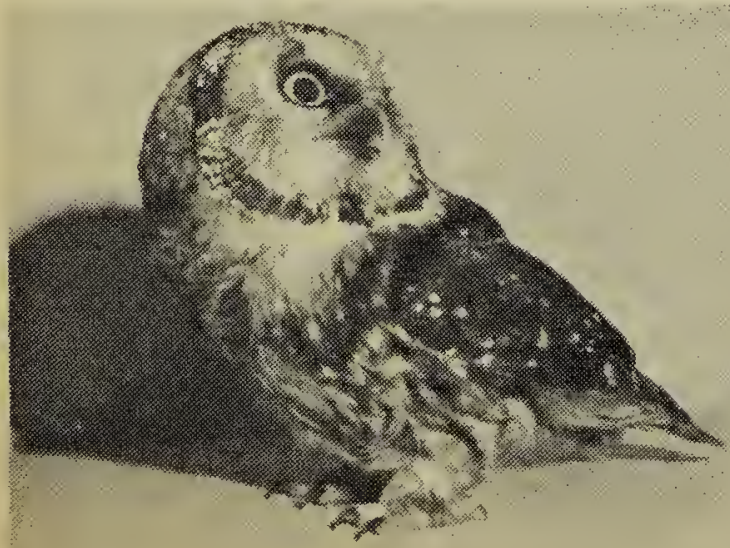

5
Keep up the good work, boys and girls, and let's hear from you often.

\section{"NAME THE BIRD" CONTEST}

Contest Rules: Any boy or girl, 16 or under, may enter this contest. Write your name, age and address at the top of the page, then number from 1-14. After each number write the name of the bird in the photograph. Clues to this contest are found elsewhere in the Boys' and Girls' Section. The answers to all of the questions are found on the Saskatchewan bird check-list. Closing date for the entries is October 15, 1960 .

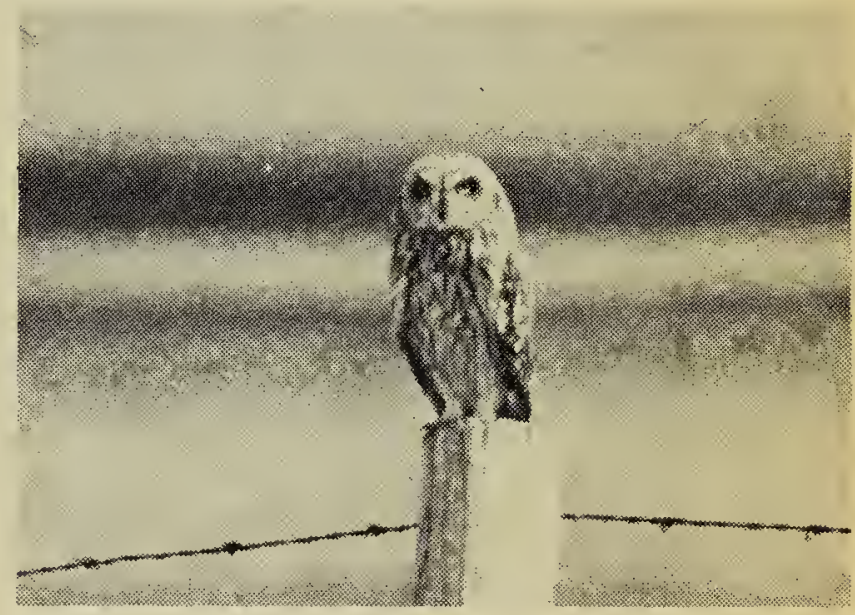

2

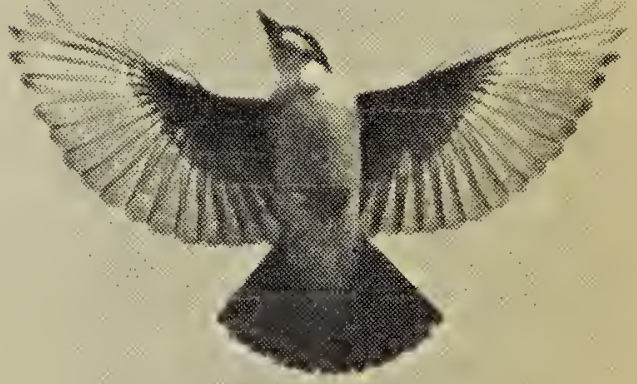

4

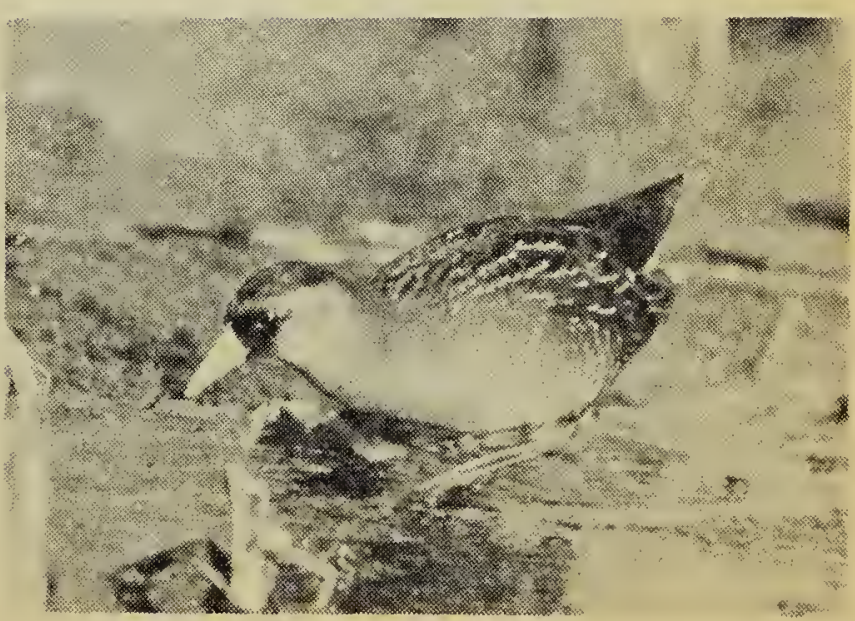

6 
Vol. XVIII No. 3
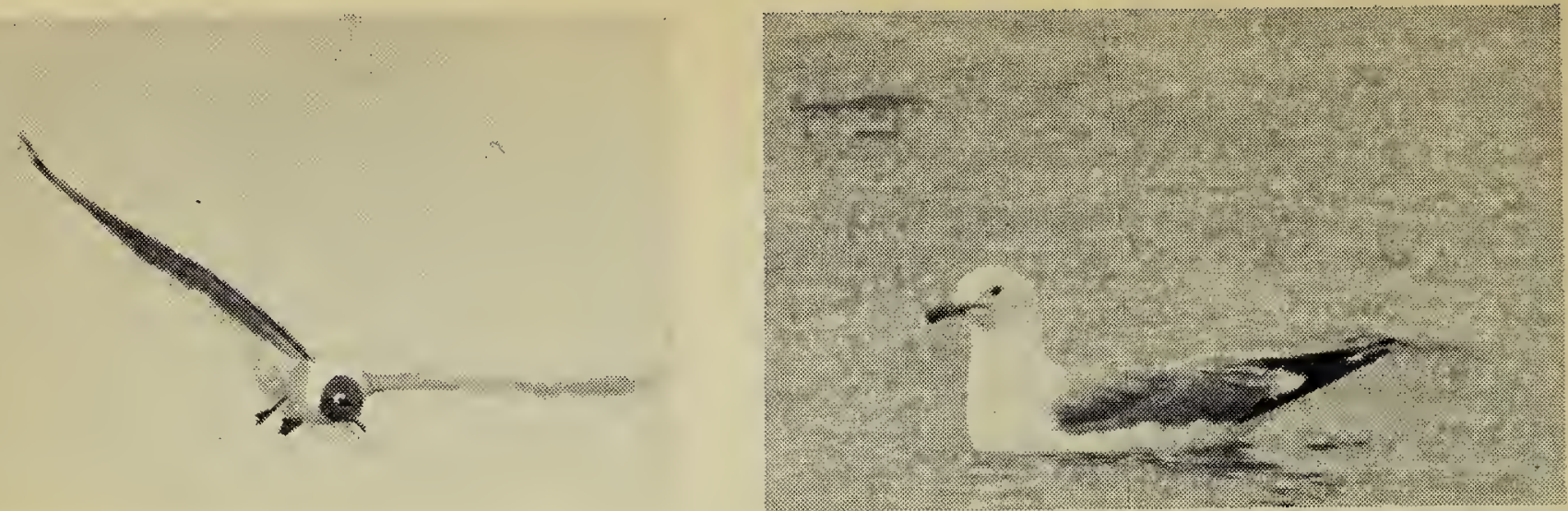

8
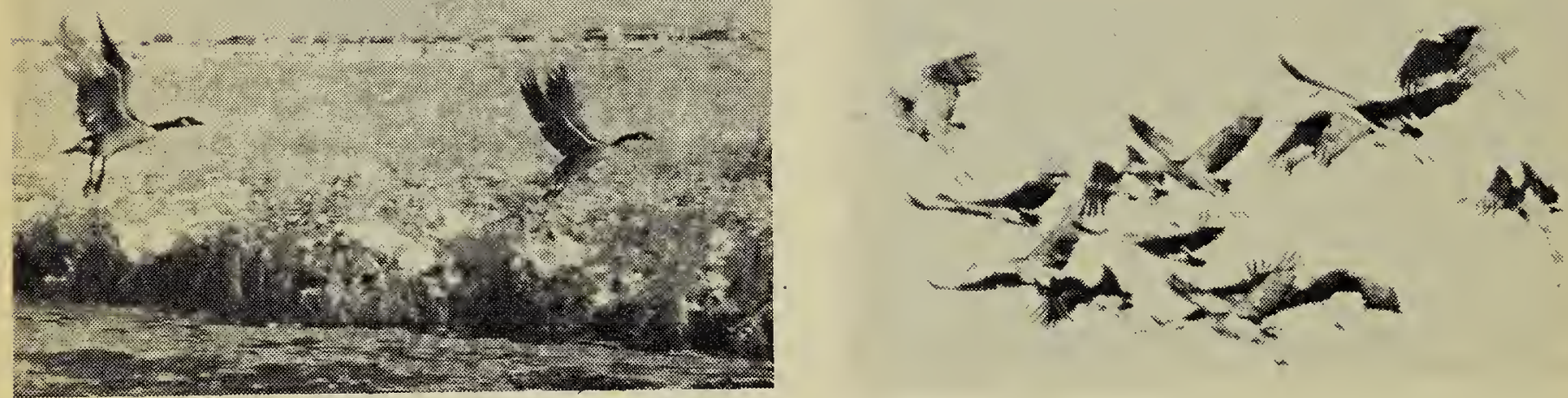

9

10

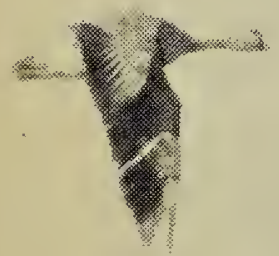

11

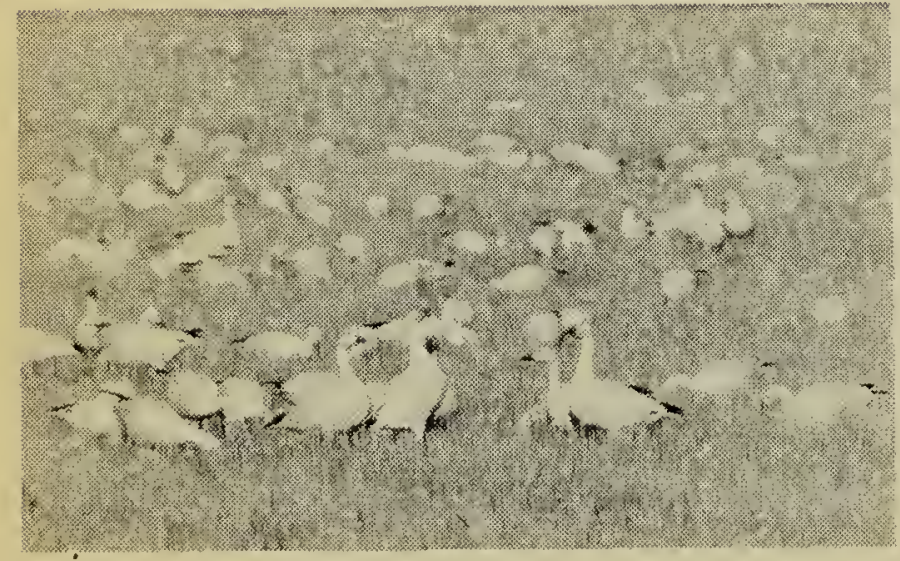

13

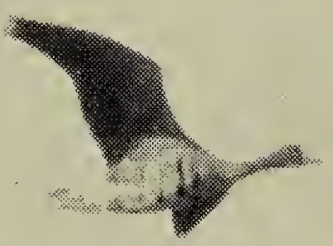

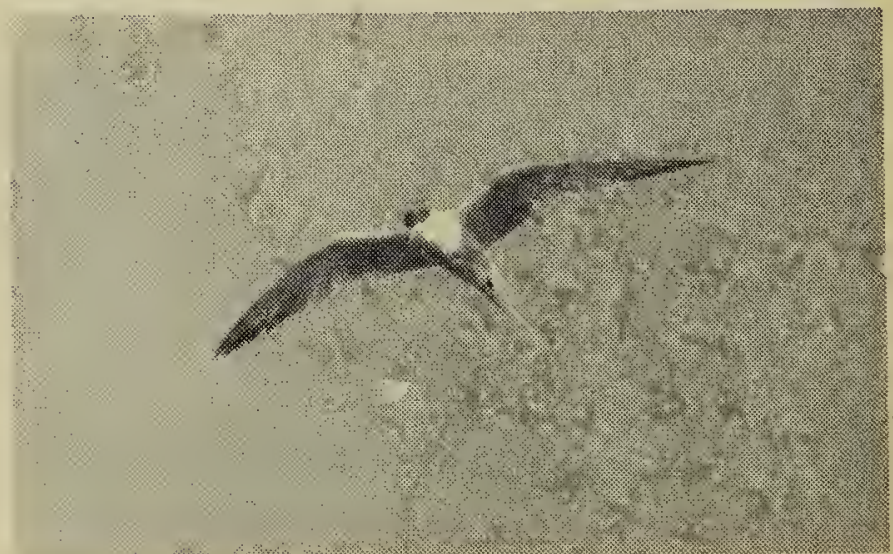

